\title{
Masarykova Univerzita Masarykova
}

\section{Masaryk's Masaryk University}

\author{
Hana Řehulková
}

Do nedávna byla u příležitosti stoletého výročí Masarykovy univerzity k vidění na Moravském náměstí netradičně pojatá busta Tomáše Masaryka od Maxima Velčovského. Ale k vidění bylo ještě něco víc než jen čtyřmetrová hlava z červených trubek. Děti, v jejichž očích se umělecké dílo pochopitelně proměnilo v lákavou prolézačku, a rodiče, kteří své ratolesti zoufale odháněli, protože lézt na sochu bylo zakázáno. Podobnost díla s dětskou prolézačkou není náhodná. Umělec dle svého vyjádření vskutku zamýšlel konstruovat sochu tak, aby umožňovala šplhání a lezení v pomyslné mysli prvního prezidenta. Nicméně vzhledem ke čtyřmetrové výšce se stěží mělo jednat o prolézačku pro děti. Skutečná Hlava 22 se však z hlavy Masarykovy stala ve chvíli, kdy bylo na toto umělecké dílo/prolézačku zakázáno lézt proto, že na umělecká díla (zjevně ani tehdy, jsou-li prolézačkami) se eo ipso lézt nesmí. Domnívám se, že Masarykovi by při pohledu na zklamané děti a uštvané rodiče přišla celá věc hloupá, smutná a zbytečná. Jaksi špatně uchopená a nanicovatá. Snad by i přivítal, kdyby už za ty peníze, vynaložené na jeho sochu, z ní byla i prolézačka pro děti. Měla by větší užitek, přinesla víc radosti. A tím měla i větší hodnotu a hlubší smysl. Možná by celé gargantuovské oslavy stoletého výročí se svým rezervovaným přístupem $\mathrm{k}$ upř́lišenému historismu obrátil raději v něco méně viditelného, ale trvalejšího. Proč jste raději nezaložili knihovnu, studijní stipendium nebo laboratoř? Co zbylo z těch oslav?

Masarykovo jméno se stalo reklamní značkou, protiargumentační taktikou, předmětem nekritického přijetí. Tedy vším tím, proti čemu Masaryk vystupoval. A kdo jiný by měl být schopen odolat pokušení využívat (či zneužívat) jméno, tvář a odkaz prezidenta osvoboditele, než univerzita Masarykova? Kde jinde než na filozofické fakultě by se měla křehká a mocná zaklínadla jako humanismus, demokracie, dialog, filozofie atd. používat pouze 
smysluplně a přiléhavě? Když 6. července 1892 hovořil Masaryk v poslanecké sněmovně o potřebě druhé české univerzity, nahlížel tento problém věcně a prakticky:

Vědecká konkurence - [...] termín, jímž chci vyjádřit všechno to, co pro mne znamená druhá univerzita $[\ldots]^{1}$

Druhá univerzita měla být posilou univerzity pražské, měla vytvářet alternativu pro učitele i žáky, a tím osvobodit bádání od hašteření a vztahových animozit bujících v monopolizovaném svatostánku vědy. Tyto zdánlivě přízemní motivy však měly sloužit především tomu, aby univerzita mohla plnit své základní úkoly, které byly podle Masaryka jednak vědecké, jednak výchovné. Tedy pěstovat českou vědu na světové úrovni -

[...] naše vědecké snahy a práce jsou však takové, že si zaslouží být známy, pěstěny a podporovány. ${ }^{2}$

- a současně prohlubovat českou národní identitu a kulturní samostatnost, kterou lze (jak Masaryk mnohokrát zdůrazňuje v České otázce) budovat jedině vzděláním:

[...] vysoké školy, jako střediště a orgán osvětné práce, jsou dovršením osvícenských ideálů Dobrovského a Kollára, jsou uskutečnění humanitního ideálu po stránce teoretické a doufám i mravní, humanitní. ${ }^{3}$

V prvním úkolu máme usilovat o „světovost“, v tom druhém však musíme být nutně sví, sebevědomí, poctiví a autentičtí. Nenapodobujme cizí univerzity, nenahlížejme přes plot k sousedům, nesnažme se být světoví svým světáctvím, ale naopak důvěrou ve svoji práci a úkol. Masarykův politický program národní - pěstujme český jazyk, českou literaturu a českou identitu - se může jevit jako uzavřená kapitola, či dokonce přežitek. Jsou-li však právě v onom druhém úkolu zakotveny specifické hodnoty českého národa, kterými jsou podle Masaryka právě s oblibou citované „ideály humanitni“, pak je nemůže-

1 MASARYK, T. G. Parlamentni projevy..., s. 215.

2 Tamtéž, s. 220.

3 MASARYK, T. G. Česká otázka..., s. 173. 
me opomíjet ani po sto letech. Už jen proto, že se tak rádi a hlasitě hlásíme k Masarykovu jménu v názvu naší drahé druhé české univerzity.

Současná honba univerzity za uznáním v úkolu prvním uvrhla do zapomnění úkol druhý. O snahách redukovat bádání a studium na konkurenční boj vysokých škol a výzkumných pracovišt seřazujících se na stupně vítězů a poražených v nejrůznějších žebříčcích a tabulkách, boj, který měří a váží mene tekel - vědění na miskách vah publikačních databází a grantových projektů, bylo napsáno mnohé a mnoho napsáno bude. Ačkoliv Masarykovo pojetí vzdělání může rezonovat s liessmannovskou kritikou falešné vzdělanosti, bylo by za prvé zbytečné, za druhé ne zcela poctivé hořekovat nad kapitalizací vědění na brněnské univerzitě, když se jedná o jev všeobecný (což ovšem nevyjadřuje souhlas s tím, že se touto středoproudou cestou do nikam vydáváme). Co je však nežádanou obětí, kterou druhá česká univerzita někdy až podbízivě přidává na oltář „světovosti“, je právě ona identita a autenticita této instituce. Bůh se, stejně jako d'ábel, skrývá v detailu. Stačí se podívat na sebeprezentaci Masarykovy univerzity. Trička s nápisem „OMG. TGM.“ a popisem „S odkazem TGM se budete mít vždy o co pevně opřít.“, reklamní lákadla na přijímací řízení filozofické fakulty hlásající, že „to (rozuměj studium) nebude snadný [...]“, nebo motto internetových stránek „milujeme vědění, to je naše filozofie“. Devalvace a legitimizovaná devastace obsahová, jazyková i významová je naneštěstí často tolerována ve veřejném prostoru, ale vnitřně nepřijatelná jako produkt instituce, jejímž základním úkolem je rozvíjet jasné, nelenivé, pokud možno přesné myšlení.

Dnes, kdo myslí, donikati musí k principiím - úryvkovitého konání a myšlení máme dost, více než snášíme $[\ldots]^{4}$

Obětuje-li se druhý úkol v prospěch prvního, neodvolávejme se na Masarykův humanismus, skrytý dle něj právě v naší identitě a autenticitě, jako na dědictví, které rozvíjíme. Opravdu se chceme vzdát pro zdání světové úrovně a pro konkurenceschopnost toho, co nás činí svými? Opravdu budeme rušit „nevýdělečné“ obory a upřednostňovat anglický jazyk před českým a podle pravidel nabídky a poptávky otevírat programy podivuhodných názvů s mlhavou představou o předmětu studia? Nebylo by užitečnější sloužit skromně výchově a vzdělání, která nás může dovést i na vrchol vědecký, než se jen drát za předními univerzitami, přestože se beztak povětšinou krčíme 
ve srovnávacích tabulkách hluboko pod nimi? V Hovorech s TGM Masaryk ř́ká: „pravda je to, co bezpečně a kriticky víme, co je skutečnost uvědomělá“ (s. 132) a svůj tzv. konkretismus vymezuje úsilím „postihovat věci a vykládat je z nich samých“ (s. 148). V obou myšlenkách je podstatná právě skutečnost. Skutečnost taková, jaká je, ne jaká by měla nebo mohla být. Masarykova univerzita je dostatečně silná, hrdá a svébytná instituce, která je schopna unést svoji skutečnost, a není nutné, aby ze sebe dělala něco, čím není. Máme-li být univerzitou Masarykovou, pak nejen s líbivým odkazem na knižní tituly Masarykových děl, ale i s jejich obsahem. A především s vědomím konání pod zorným úhlem věčnosti.

Masarykova socha od Vincence Makovského na Komenského náměstí stojí kromě svátků a období kladení věnců většinou nepovšimnuta. Zvláštní pozornosti se jí nedostalo ani během stoletých výročí univerzity, ač tu věrně v dešti a větru stojí se svou univerzitou v zádech po nemálo let. Zobrazuje Masaryka zahloubaného, zmlklého, bez pompézních gest, nevůdcovsky, nevelikášsky. Netrápí děti, ani rodiče. Odráží více z prezidentova a myslitelova odkazu jeho druhé univerzitě než mnohé olbřímí, halasné, nepřehlédnutelné atrakce.

\section{Použitá literatura}

MASARYK, T. G. Česká otázka. Státní nakladatelství: Praha 1924.

MASARYK, T. G. O naši nynějš̌ krisi. Státní nakladatelství: Praha 1924.

MASARYK, T. G. Parlamentní projevy 1891-1893. Masarykův ústav AV ČR: Praha 2011. ČAPEK. K. Hovory s TGM. Československý spisovatel: Praha 2012.

\section{Mgr. Hana Řehulková, Ph.D.}

Seminář estetiky, Filozofická fakulta, Masarykova univerzita

Arna Nováka 1, 60200 Brno, Česká republika

hanarehulkova@mail.muni.cz 